日薬理誌 $57,520 \sim 537$ (1961)

\title{
発熱物質に関する研究 (16)
}

発熱物質丈は諸種薬物適用時に出ける心内温, 直腸温, 筋温

の各変化と心電図との関係

安田学

(京都大学医学部薬理学教室)

(昭和 36 年 2 月 27 日受付)

緒言

心葴或は末梢血管に対し強い影響を与兄る諸種薬物に上る体温の变化についてはすでに Deutsch たる 1,2),

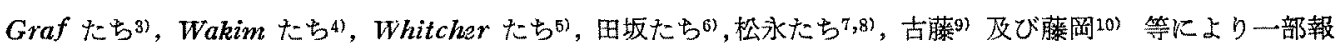

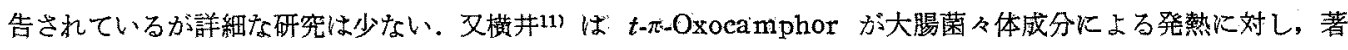

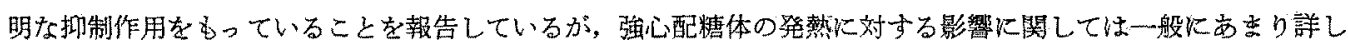
く知られているとは云京ない，私はそこで前報12》代訅した如き右心カテーテル法に一部，左心カテーデル法を 併用し，発熱济する二，三薬物の影響及び諸種薬物による正常体温の变化を，同時に記録した心電図（ECG） の所見とくらべながら检討してみだのでここに報告なる。

\section{実 黖 方 法}

\section{1）実駼動物，体温測定方法及び ECG 記録方法}

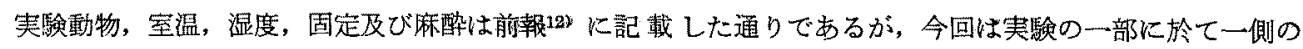
総頸動脈を露出し，右心カテーテル法の術式に準じて左心室内にもカテーテルを插入し，尖端に装置したサーミ スターで左右心内温を同時に测定した。筋温は外佳䄪 $1 \mathrm{~mm}$ の注射針型サーミスターを大腿内転笳に刺入して 測定し，直腸温は外径約 $5 \mathrm{~mm}$ のカテーテルに装置したサーミスターを肛門から約 $6 \mathrm{~cm}$ 雨入して測定した。 そしてこれらの温度はすべて自動記銀装置に上り連緢記録が出来るよらにした。

ECG は熱ペン直記式心電計を使用し，第I誘導で記録， $1 \mathrm{mV}$ が $1 \mathrm{~cm}$ の大きさに振れるように調整し，記 録紙の搬送速度は $5 \mathrm{~cm} / \mathrm{sec}$ 或は $2.5 \mathrm{~cm} / \mathrm{sec}$ とした。本論文中の各図の：ECG は記録㼏の 1 目盛が $1 \mathrm{~mm}$ に なっている。従つて搬送速度が $5 \mathrm{~cm} / \mathrm{sec}$ 或は $2.5 \mathrm{~cm} / \mathrm{sec}$ の場合は1目盛がそれそれ 1/50 sec，1/25sec に相 当する。な和実験はウサギ（雄）について各タ 5 例づつ行った。

\section{2) 使用器具の消毒及び注射方法}

前報12) と同様である

\section{3）使用した発熱物頭，薬物及び血液試料}

a) チフ六菌ワクチンは生理食塩水 $1.0 \mathrm{cc}$ 中, チフス菌 (米国株) 死菌 $1 \mathrm{mg}$ 含むものを $60^{\circ} \mathrm{C} て ゙ \quad 1^{\mathrm{h}}$ 隇 菌し，更にその $1.0 \mathrm{cc}$ 中に死菌が 0.1mg 含ま机るように調製した。 T.T.G. 及び 2, 4-Dinitrophenol は前 報12) と同様である。

b) $g$-Strophanthin (Uabanin 武田薬工)

c) $t-\pi$-Oxocamphor (Vitacampher 吉富製薬)

d) l-Adrenaline $\mathrm{HCl}$ (Bosmin 第一製薬)

e) Imidalin (山之内)

f) Acetylcholine chloride (Ovisot 第一製薬)

g) Atropine sulfate (志紀)

h) Quinidine Sulfate 
すべて1\%減菌水溶液とし pyrogen free であることを確認後使用した.

i) Digitamin(塩是義): 1cc 中ジギタリス葉グリコシッド 0.4 0.6フォッケ単位含有のものを使用した.

j）血夜試料：予め局方クエン酸ナトリウムの $10 \%$ 減菌水溶液で内部をしめした注射器を用い，健康な家

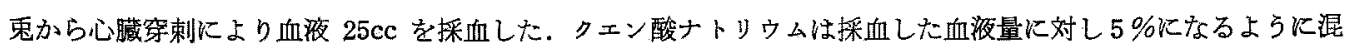
和した．この血液に前記チフス菌ワクチン $2 \mathrm{cc}$ を加克, $37^{\circ} \mathrm{C} て ゙ 1^{\mathrm{h}}$ incubate L, 2000 r.p.m. 以上で $20^{\mathrm{m}}$ 遠心 沈澱して䄪 $15 \mathrm{cc}$ の血漿を分離し得た. 従ってこの血漿 $7.5 \mathrm{cc}$ は約 $1 \mathrm{cc}$ のチフス菌ロクチンを含むと推定され るので, 実験漈してはその $7.5 \mathrm{cc} / \mathrm{kg}$ を静注した. 刘照実験には pyrogen free の生理食塩水 $4 \mathrm{cc}$ にチフス 菌ワクチン $1 \mathrm{cc}$ を加总, $37^{\circ} \mathrm{C}, 1^{\mathrm{h}}$ incubate した後, $5 \mathrm{cc} / \mathrm{kg}$ 省静注した.

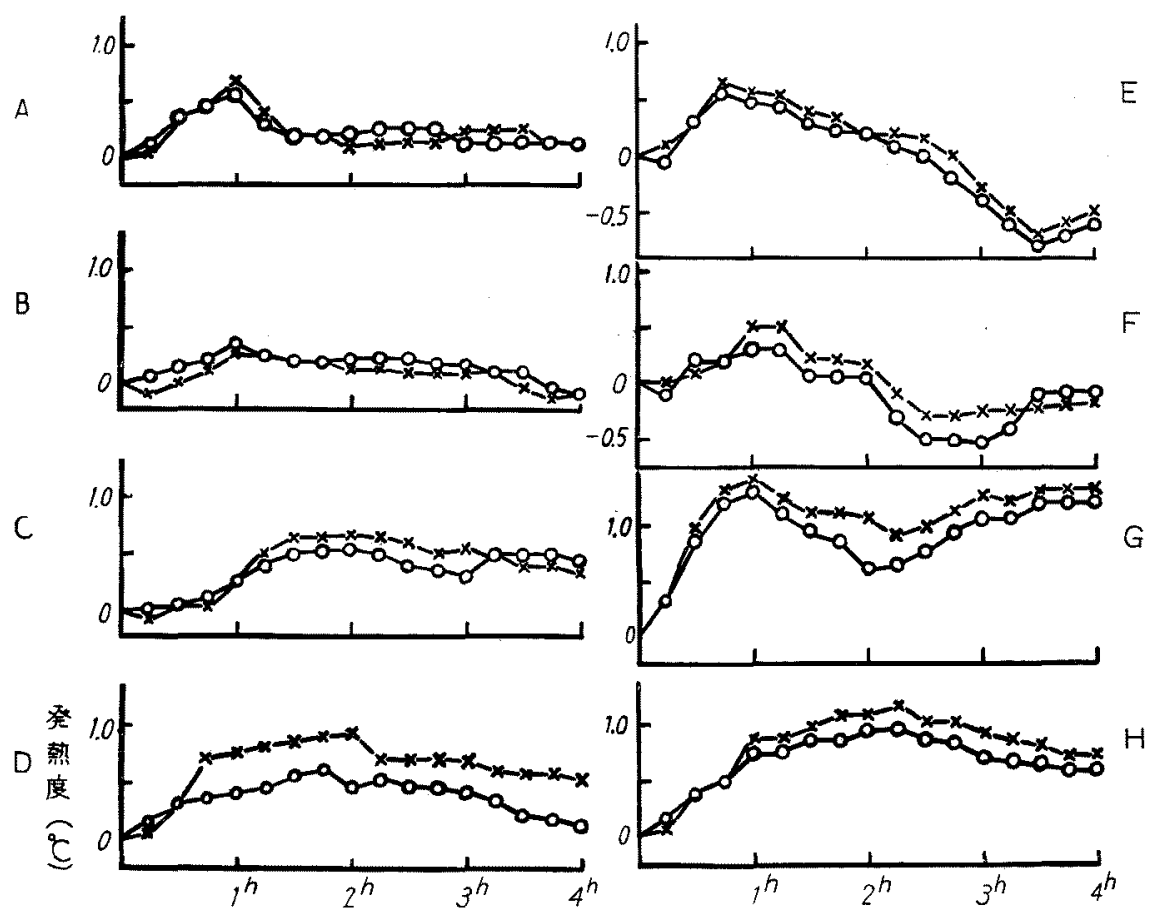

時間 -

第 1 図，背位固定家鬼の発熱に対する $t-\pi$-Oxocamphor, $g$-Strophanthin 及び Digitamin の影響
A) チフス菌ワクチン $0.1 \mathrm{mg} / \mathrm{kg}$ と $t-\pi$-Oxocamphor $5 \mathrm{mg} / \mathrm{kg}$ を混注,
B) チフス菌ロクチン $0.1 \mathrm{mg} / \mathrm{kg} と g$-Strophanthin $0.06 \mathrm{mg} / \mathrm{kg}$ を混注,
C) チフス菌ワクチン $0.1 \mathrm{mg} / \mathrm{kg}$ と Digitamin $1 \mathrm{cc} / \mathrm{kg}$ を混注,
D) チフス菌ワクチン $0.1 \mathrm{mg} / \mathrm{kg}$ 静注 (対照)，
E) 血液一チフス菌ロクチン $7.5 \mathrm{cc} / \mathrm{kg}$ と $t-\pi$-Oxocamphor $7.5 \mathrm{mg} / \mathrm{kg}$ を混注,
F) 血液一チフス菌ワクチン $7.5 \mathrm{cc} / \mathrm{kg}$ と g-Strophanthin $0.06 \mathrm{mg} / \mathrm{kg}$ を混注,
G) 血液一チフス菌ワクチン $7.5 \mathrm{cc} / \mathrm{kg}$ 静注 (対照)，
H) 生理食塩水一チフス菌ワタチン $5 \mathrm{cc} / \mathrm{kg}$ 静往 (対照) .
$\mathrm{O}-\mathrm{O}$ : 心内温, $x-x$ : 直腸温.

\section{実 験 成 績}

\section{A. 諸種発熱因子による発熱に対する $t-\pi$-Oxocamphor, g-Strophanthin 及び Digitamin の影響}

1) チフス菌ワクチン $0.1 \mathrm{mg} / \mathrm{kg} と t-\pi-O x o c a m p h o r ~ 5 \mathrm{mg} / \mathrm{kg}$ を混注した場合

混注後の初期汸於ては心内温の上年度は直晹温のそれより稍々大であったが，約 $30^{\mathrm{m}}$ を過ぎる頃から活ぼ 
同程度となり，時間の経過とともに直腸温の発熱度の方が稍々大となって殆んど同じ頃に peak に達した

(第 1 図A).

その後は两温とも次第に下降し，発熱曲線は図の上5に接近している。これを対照（第1図D）のチフス菌 ワクチン $0.1 \mathrm{mg} / \mathrm{kg}$ 静注の場合と比較すると，混注時には両温とも対照にくらべて早く peak に達するが最高 発熱度は低い。

2) チフス菌ワクチン $0.1 \mathrm{mg} / \mathrm{kg}$ と g-Strophanthin $0.06 \mathrm{mg} / \mathrm{kg}$ を混注した塨合

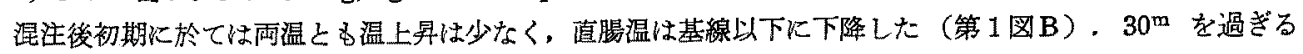
頃からは直腸温も次第に上年し，二温は殆んど同じ頃に peak に達した。発熱曲線は互に接近しているが $4^{\mathrm{h}}$ で全経過を通でて心内温の発熱度の方が稍々高かった。これを対照と比較すると, 混注した場合の方が二温とも peak が早く，発熱度は著しく低い。

3）チフス菌ワクチン $0.1 \mathrm{mg} / \mathrm{kg}$ とDigitamin $1 \mathrm{cc} / \mathrm{kg}$ を混注した場合

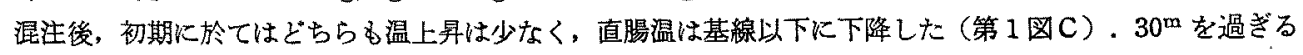
頃から直腸温も次第に上䄯し，二温は殆んど同じ頃に peak に達した. $1^{\mathrm{h}}$ から $3^{\mathrm{h}}$ までは直腸温の上昇度の方 が大であった。 これを対照と比較すると，peak の时期には殆んど差がないが，発熱度は二温とも低い。

4) T.T.G. $15 \mathrm{r} / \mathrm{kg}$ と $t$ - $\pi$-Oxocamphor $5 \mathrm{mg} / \mathrm{kg}$ を混注した場合

対照（第 2 図B）の T.T.G. $15 r / \mathrm{kg}$ 静注の場合と添ぼ同様な発熱曲線を示すが, 発熱度は二温とも対照に くらべて稍々低からた.

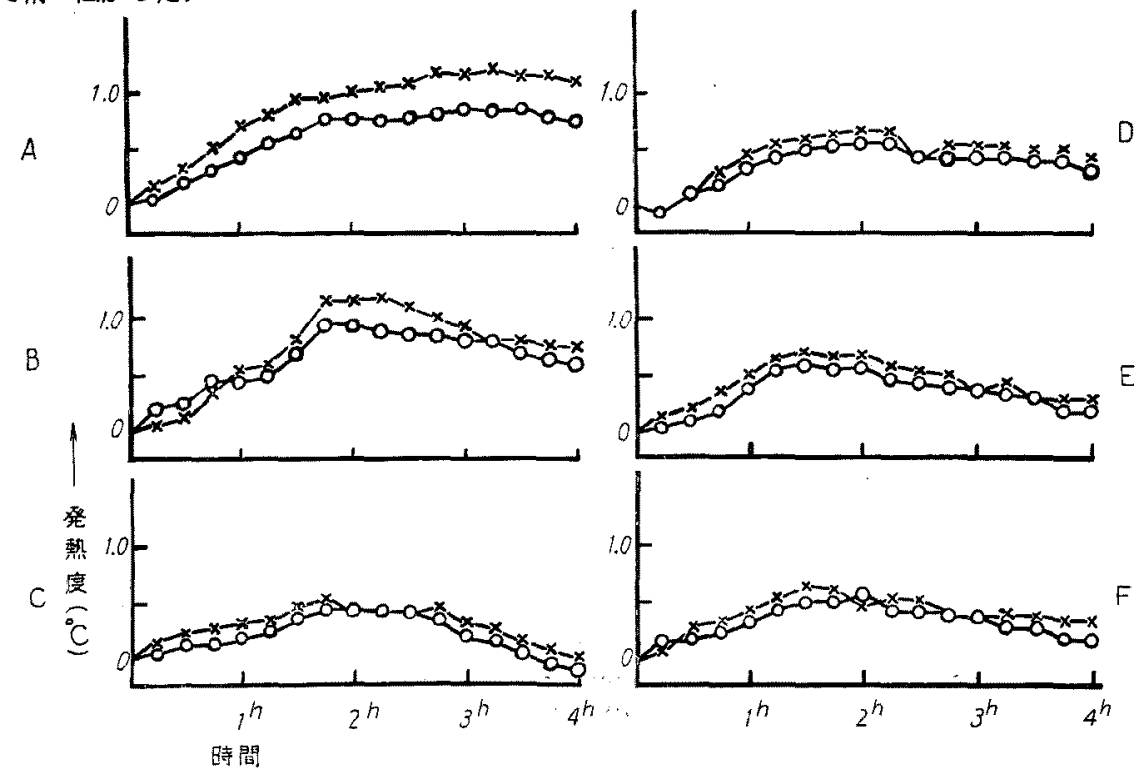

第 2 図. 背位固定家鬼の発熱代対する $t$ - $\pi$-Oxocamphor 及び $g$-Strophanthin の影響
A) T.T.G. $15 \gamma / \mathrm{kg}$ と $g$-Strophanthin $0.06 \mathrm{mg} / \mathrm{kg}$ を混注,
B) T.T.G. $15 \gamma / \mathrm{kg}$ 静注 (対照)，
C) DNP $10 \mathrm{mg} / \mathrm{kg} と \mathrm{~g}$-Strophanthin $0.06 \mathrm{mg} / \mathrm{kg}$ を混注,
D) DNP $10 \mathrm{mg} / \mathrm{kg}$ と $t$ - $\pi$-Oxocamphor $5 \mathrm{mg} / \mathrm{kg}$ 混注,
E) DNP $10 \mathrm{mg} / \mathrm{kg}$ \& $t-\pi$-Oxocamphor $7.5 \mathrm{mg} / \mathrm{kg}$ を混注，
F) DNP $10 \mathrm{mg} / \mathrm{kg}$ 静注 (対照) 。

$O-O$ : 心内温, $x-x$ : 直腸温.

5) T.T.G. $15 r / \mathrm{kg} \& g$-Strophanthin $0.06 \mathrm{~kg} / \mathrm{kg}$ を混注した場合

第 2 図Aのように直腸温の上昇度の方が大さい, peak の時期は心内温の方が稍々早かつた。対照と比較す 


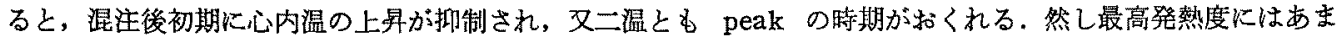
り差がなかった。

6) DNP $10 \mathrm{mg} / \mathrm{kg}$ と $t-\pi-0$ xocamphor $5 \mathrm{mg} / \mathrm{kg}$ を湿注した場合

混注後, 初期に於ては二温とも基線以下儿下降したがその後次第に上年し，ほぼ同じ頃に peak に達し た. 発熱度は直腸温の方が大であった. 対照（第 2 図F）の DNP $10 \mathrm{mg} / \mathrm{kg}$ 静注の場合と比較すると，初期に 発熱の抑制があるが，混注後約 $30^{\mathrm{m}}$ 経過すると二温とも対照とほぼ同程度の発熱を生じた。 peak の時期はど ららを対照にくらべて稍々执くれている(第2図D).

7) DNP $10 \mathrm{mg} / \mathrm{kg} と t$ - $\pi$-Oxocampher $7.5 \mathrm{mg} / \mathrm{kg}$ を湿注した場合

温上䄯度は直晹温の方が稍々大であった，又一温ともほぼ同じ頃に peak に澾した，対照と比較すると， 初期には混注した場合の心内温の方が稍々低いが，直腸温の上界度には殆んど差が見られなかった。時間が経過 するにつれて，二温とも対照と同程度か或は淞々高い発熱を生じた（第 2 図 $\mathrm{E}$ )。

8） DNP $10 \mathrm{mg} / \mathrm{kg}$ とg-Strophanthin $0.06 \mathrm{mg} / \mathrm{kg}$ を混注した場合

二温の発熱曲線が互に接近する時期もあるが，大体に於て直晹温の発熱度の方が大であった。 peak の時期 は対照の場合と同様に直腸温の方が稍々早い. 混注の場合には対照と比較して, 初期の心内温の上界が少なく， 二温の最高発熱度も各々対照上り稍々低い（第 2 図C).

9）血液ーチフス菌ワクチンと $\boldsymbol{t}-\pi$-Oxocamphor $7.5 \mathrm{mg} / \mathrm{kg}$ を混注した場合

実験方法 j) でのべた血液一チフス菌ワクチン $7.5 \mathrm{cc} / \mathrm{kg}$ の静注では, 生理食塩水一チフス菌ワクチン $5 \mathrm{cc} / \mathrm{kg}$ 静注の場合にくらべて, 発熱までの潜伏期間が一䊬短くなり発熱は增強される. 又血液一チフス菌 ワ

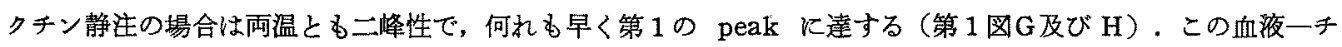
フス菌ワクチンと $t$ - $\pi$-Oxocamphor を混注すると，湝注後初期に於ては，心内温は基線以下に下降したが直腸 温は僅かな温上年を生した．30m 以後は心内温も上型した。対照の血液一チフス菌ワクチン単独静注の場合と比 較すると，混注したものでは心内温及び直腸温の発熱度は著しく抑制され，各々の peak も稍々早い（第 1 図 E).

10）血液ーチフス菌ワクチン $7.5 \mathrm{cc} / \mathrm{kg}$ と-Strophanthin $0.06 \mathrm{mg} / \mathrm{kg}$ を混注した場合

混注後, 初期に於ては心内温恃基線以下に下降したが, 直腸温は僅かな温上界を生じた. $30^{\mathrm{m}}$ 以後は心内 温も上年した．対照の血液一チフス菌ワクチン単独静注の場合と比較すると，混注したものでは二温とも発熱度 は著しく抑制されたが，各々の peak の時期にはあまり差が見られなかった（第1図F）。

B. 正常家鬼の左右心内温, 直腸温及び筋温に対する諸種薬物の影響

1) $t$ - $\pi$-0xocamphor

$t$ - $\pi$-Oxocamphor $7.5 \mathrm{mg} / \mathrm{kg}$ を静注すると右心内温，左心内温及び直腸温は静注後 $5^{\mathrm{m}}$ (因では示されてい ない. 以下同様〉ではそれぞれ $0.1 ， 0.1$, 及び $0.2^{\circ} \mathrm{C}$ の温下降を生じたが, 約 $30^{\mathrm{m}}$ では左右心内温は回復 し，右心内温は僅かな温上昇を生じた．然し直腸温は回復がおくれて約 $1^{\mathrm{h}}$ むでは基線より稍々低かった。 $1^{\mathrm{h}}$ 以後は三温とも多小の変動はあったが渐次上身の傾向を示し， $4^{\mathrm{h}}$ 後の温上年は左心内温並に直晹温は添同程 度であったが，右心内温の温上界はそれらより稍々大であった（第３図B）。

\section{2) g-Strophanthin}

$g$-Strophanthin $0.075 \mathrm{mg} / \mathrm{kg}$ を静注すると左右心内温及び直晹温はそれぞれ $5^{\mathrm{m}}$ では殆んど変化がなかっ た. 約 $15^{\mathrm{m}}$ での温上界度は右心内温並に直腸温はほぼ同程度であったが，左心内温はそれらょり稍々大であっ た. 左心内温はその後 $4^{\mathrm{h}}$ まで僅かではあるが温上年を続けた。. 右心内温は其の後静注前温度まで低下したが， 約 $2^{\mathrm{h}}$ 以後洅び上年した．直腸温の上年度は約 $30^{\mathrm{m}}$ で最高上なり其の後は次第に基線以下に下降した（第 3

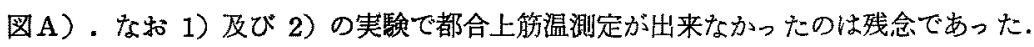

\section{3) Digitamin}

Digitamin $1.5 \mathrm{cc} / \mathrm{kg}$ 静注すると, 静注後 $5^{\mathrm{m}}$ では左右心内温, 直晹温及び筇温は各々不変か又は僅か な温下降を生したが，15 $\mathrm{m}$ では何れも基線以下に下降した，然し的 $30^{\mathrm{m}}$ では左心内温だが僅かに上畀したが 
A
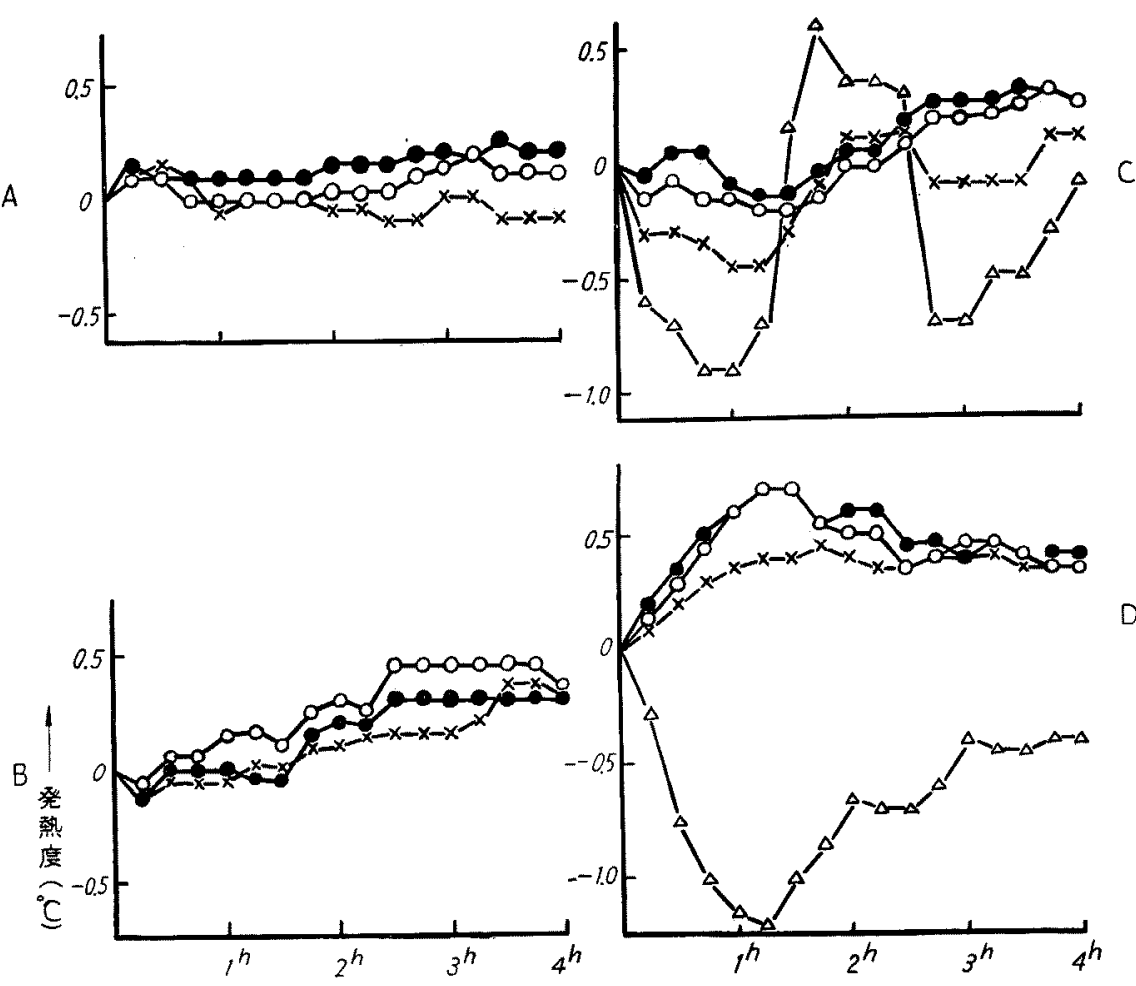

時間

第 3 図，背位固定正常家鬼の心内温，直腸温及び筋温に対する各薬物の影響

A) $g$-Strophanthin $0.075 \mathrm{mg} / \mathrm{kg}$ 静注,

B ) $t-\pi$-Oxocamphor $7.5 \mathrm{mg} / \mathrm{kg}$ 㟊注,

C) Digitamin $1.5 \mathrm{cc} / \mathrm{kg}$ 静注,

D) Digitamin $2.0 \mathrm{cc} / \mathrm{kg}$ 静注.

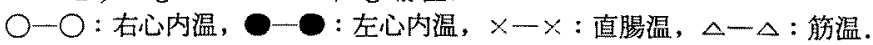

間もなく基線以下に下降した。的 $1^{\mathrm{h}} 30^{\mathrm{m}}$ で筋温は上界し初め，他の三温も少し沶くれて同様な傾向を示した。

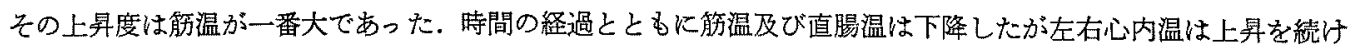
た. 䄪 $4^{\mathrm{h}}$ 後では左心内温の上界が最も大であった(第 3 图C).

Digitamin $2 \mathrm{cc} / \mathrm{kg}$ の静注では, 静注後 $5^{\mathrm{m}}$ では $1.5 \mathrm{cc} / \mathrm{kg}$ 静注の場合と注ぼ同様であったが, 約 $15^{\mathrm{m}}$ で は左右心内温及び直腸温は僅かではあるが上年し初めた。然し筋温だけは基線以下に下降したままであった，約 $1^{\mathrm{h}} 30^{\mathrm{m}}$ では左右心内温及び直腸温の上界は最高となり，筋温も回復の㑯向を示した。温上昇度は大体に於て左 心内温が最も大であった（第 3 図D）。

\section{4) Adrenaline}

Adrenaline $25 \gamma / \mathrm{kg}$ を静注すると，静注後約 $5^{\mathrm{m}}$ では温上年度は右心内温，左心内温，直腸温の順に小さ くなったが，筋温は基線以下に下降した．其の後左右心内温は $30^{\mathrm{m}}$ で稍々低下したが， $1^{\mathrm{b}}$ を過ぎる頃から再 び上年し初めた。直腸温は $15^{\mathrm{m}}$ を過ざる頃から基線以下に下降し，約 $1^{\mathrm{h}}$ で回復し更に僅かな温上年を生じた が，約 $3^{\mathrm{h}}$ 以後住び基線以下に下降した．筇温は常に基線以下であった（第 4 図A）. Adrenaline $15 \mathrm{r} / \mathrm{kg}$ でも各温はこれとほぼ同㥞な傾向を示した。 

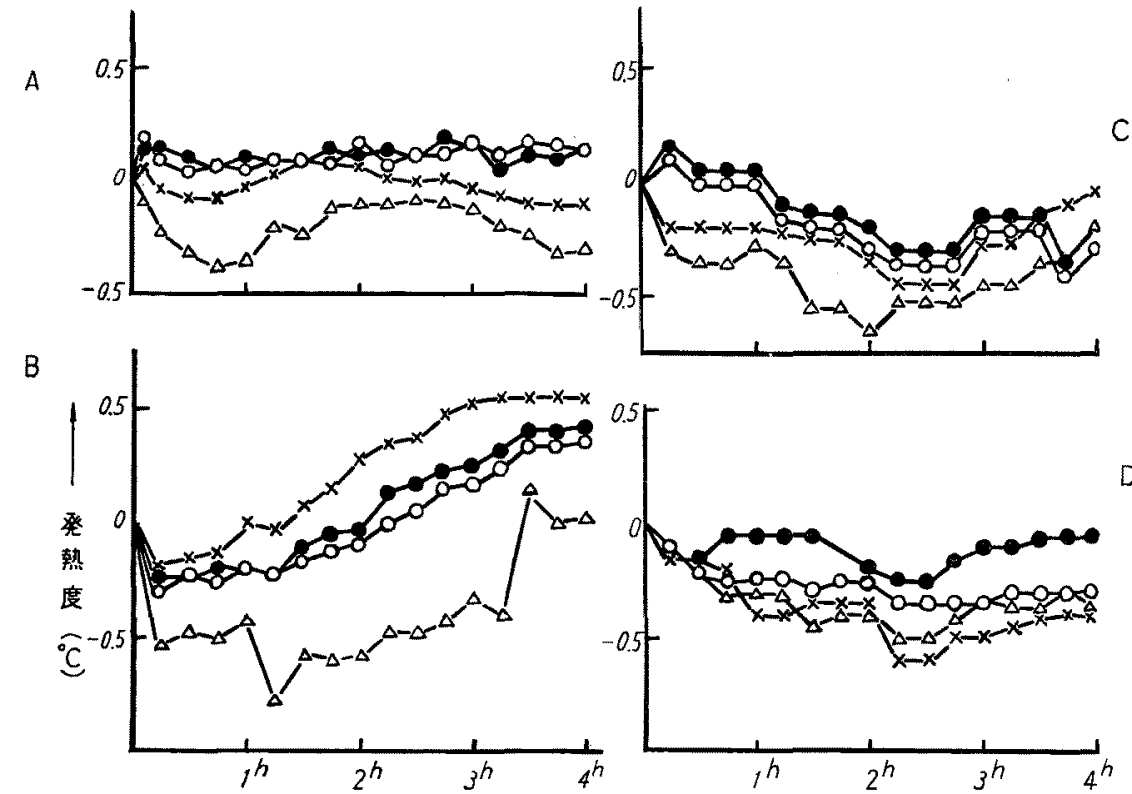

時間 -

第 4 図. 背位固定正常家鬼の心内温，直晹温及び筋温に対する各薬物の影響
A) Adrenaline $25 \mathrm{r} / \mathrm{kg}$ 静注,
B) Imidalin $2.5 \mathrm{mg} / \mathrm{kg}$ 静注,
C) Acetylcholine $25 \% / \mathrm{kg}$ 静注,
D) Acetylcholine $50 \mathrm{r} / \mathrm{kg}$ 静注.

$\bigcirc$ 一 : 右心内温, -0 : 左心内温, $x-x$ : 直腸温, $\Delta-\Delta$ : 筋温.

\section{5) Imidalin}

Imidalin $2.5 \mathrm{mg} / \mathrm{kg}$ の静注で各温は何れる基線以下に下降し, その下降度は $5^{\mathrm{m}}$ では直腸温, 筋温, 右心 内温, 左心内温の順に小ざくなたが, 約 $15^{\mathrm{m}}$ では筋温, 右心内温, 左心内温, 直晹温の順に小さくなった。

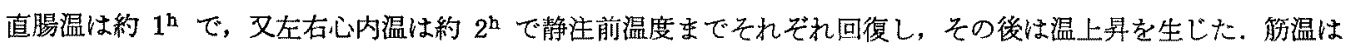
最もおくれて回復した（第 4 図B）。

\section{6) Acetylcholine}

$\mathrm{ACh}$ を $25 r / \mathrm{kg}$ 静沬すると, 静注後 $5^{\mathrm{m}}$ では筋温だけが僅かな温上䒜を生じ, 他の三温は何れも基線以下

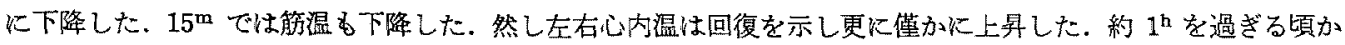
らは四温ともすぺて基線以下で多小の変動を示しながら経過した. 下降度は大体に於て左心内温が最も少なかっ た（第 4 図C）.

ACh $50 \% / \mathrm{kg}$ 静注では, 静注後 $5^{\mathrm{m}}$ で筀温だけは矢張り僅かな温上年を生じたが, 他の三温は不変か又仕 基線以下に下降した. 静注後 $15^{\mathrm{m}}$ 以上経過すると四温ともすべて基線以下に下降し多少の変動を示した. 左心 内温の下降度は最も少なかった（第 4 図D）。

\section{7) Atropine}

Atropine $0.5 \mathrm{mg} / \mathrm{kg}$ の静注では静注後 $5^{\mathrm{m}}$ で筋温のみが上年するが，他の三温は不变か又は基線以下に 下降した。約 $1^{\mathrm{h}}$ を過ぎると筋温も基線以下に下降した，下降度は笳温が最も少なく右心内温が最も大であった (第 5 図A）。 
Atropine $0.75 \mathrm{mg} / \mathrm{kg}$ の静注では, 静注後 $5^{\mathrm{m}}$ で， $0.5 \mathrm{mg} / \mathrm{kg}$ 静进の場合とは这に笳温だけが基線 以下に下降し，他の三温は僅かな温上昇を生じた。 15 mでは筋温む静注前温度まで回復するが, 約 $30^{\mathrm{m}}$ 以 後は四温何れる静注前温度又はそれ以下に下降した

(第 5 园B）。

\section{8) Quinidine}

Quinidine $10 \mathrm{mg} / \mathrm{kg}$ の竫注では，静注後 $5^{\mathrm{m}}$ で左心内温及び筇温の僅かな下降を来すが，右心内湜 及び直腸温は殆えど变らなかつた．約 $15^{\mathrm{m}}$ では右心 内温及び直儤温も僅か儿基線以下に下降するが，左心 内温は静注前温度まで回復した. $30^{\mathrm{m}}$ 以後は四温とも 多少の変動を示しながら，静注前温度か又はそれ以下 で経過した。四温の発熱曲綜は複雑である

(第 5 図C).

C. ECG の変化

1）サーミスター㨀入による変化

サーミスター（以下「サ」と略す）㨀入直後には 洞性或は心室性不整脈が見られることがあるがいずれ も一過性であり, 多くは数分以内に消失し $20^{\mathrm{m}}$ 以上 経過してもな和不整派を見ることは少ない，插入直後 の不整脈は特に左右心室に「サ」を插入した際に多く 見られた（第 6 图A）。不整脈以外の変化としては PP の延長，QT 及び QRS 軽度の延長，Pの軽度 短樎， R增高及びT減高等の見られることが多いが， 「サ」聥入直後にR減高の見られたるのるあった。こ れらの変化も多くは $1^{\mathrm{h}}$ 以内に消失したが，時にはそ れ以上続く量合もあり，特に PP の延長上Tの減高は 軽度ではあったが長く続いた例もあった（筆6図B及 ぴC).
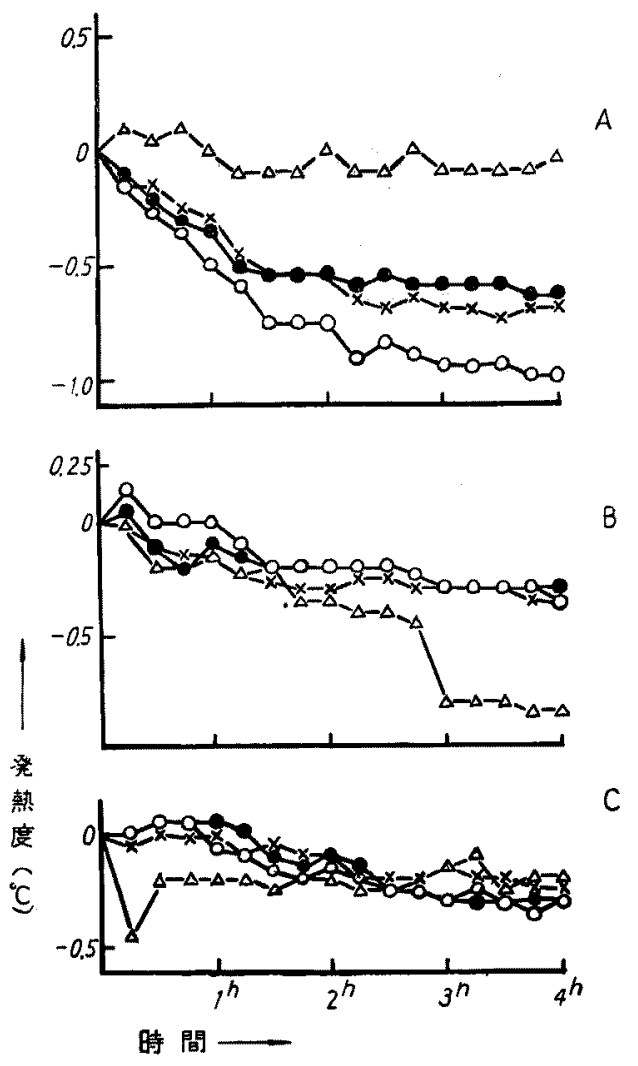

第 5 図. 背位固定正常家鬼の心内温, 直腸温及び 筋温に対する各薬物の影響

A) Atropine $0.5 \mathrm{mg} / \mathrm{kg}$ 静注,

B) Atropine $0.75 \mathrm{mg} / \mathrm{kg}$ 静注,

C) Quinidine $10 \mathrm{mg} / \mathrm{kg}$ 静注.

○一○: 右心内温, - : 左心内温, $\times$ × : 直晹温, $\triangle-\Delta:$ 管温.

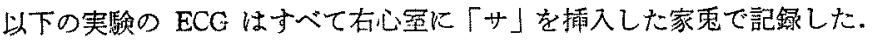

2) チフス菌ワクチン発熱時の ECG

a) チフス菌ワクチン $0.1 \mathrm{mg} / \mathrm{kg}$ を静注した場合

「サ」捙入家秉のチフス囷ワクチン発熱時の ECG は「サ」㨂入直後の変化を除いては，背位固定だけ行っ た家秉の発熱時 ECG とほぽ同樣で，轾度ではあるが PP，P 及び QT の短縮，P及びTの減高が見られた。 Pが增高する例もあった．然しST の deviation はこの適用量では殆んど見られなかった（第 6 図D）。

b) チフス菌ワクチン $0.1 \mathrm{mg} / \mathrm{kg}$ と $t$ - $\pi$-Oxocamphor $5 \mathrm{mg} / \mathrm{kg}$ を混注した場合

チフス菌ワタチン単独静注の場合と特にことなった変化はないが，QRS の埾度延長及びR增高の見られる ことが多かった（第 6 图 $\mathrm{E}$ ). QT の軽度延長も見られた.

c) チフス菌ワクチン $0.1 \mathrm{mg} / \mathrm{kg}$ と $g$-Strophanthin $0.06 \mathrm{mg} / \mathrm{kg}$ を湿注した堨合

チフス菌ワクチン単独静注の場合と特にことなった変化はないが, PP 短維, QT 延長及び P增高が見られ た(第 6 図F). 


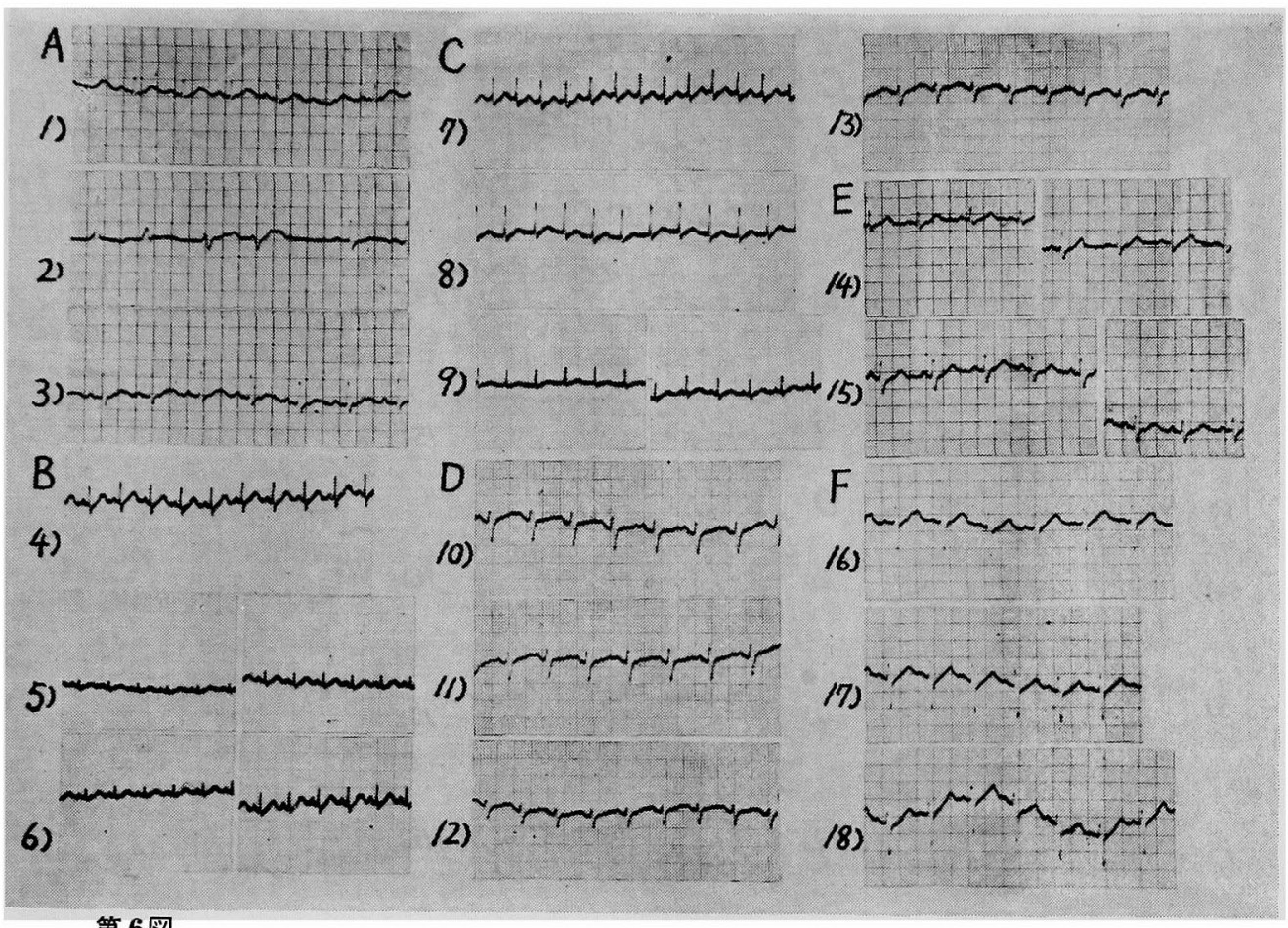

第 6 図。
A)
1）背位固定正常家鬼（対照），
2）左右心室にサーミスター挿入後 $10^{\mathrm{s}}$,
3) 左右「サ」後 $20^{\mathrm{m}}$,
B)
4）背位固定正常家鬼（対照），
5）右心室にサーミスター插入後 $10^{s}$ 及び $30^{\text {s, }}$
6) 右 $「+」$ 後 $1^{\mathrm{m}}$ 及び $2^{\mathrm{m}}$,
C)
7）背位固定正常家鬼（対照）,
8）左心室にサーミスター挿入後 10 ,
9）左「サ」後 $1^{\mathrm{m}} 30^{\mathrm{s}}$ 及び $2^{\mathrm{m}}$,
D)
以下各図の ECC はいずれも「サ」插入家躳について行ったものである
10）右「サ」家鬼にチフス菌ワクチン $0.1 \mathrm{mg} / \mathrm{kg}$ 静注直前（対照）,
11）静注後 $5^{\mathrm{m}}$ （「サ」雨入家鬼, 以下同様）,
12）静注後 $30^{\mathrm{m}}$,
13）静注後 $2^{\mathrm{h}}$,
E)
14）チフス菌ワクチン $0.1 \mathrm{mg} / \mathrm{kg}$ と $t$ - $\pi$-Oxocamphor $5 \mathrm{mg} / \mathrm{kg}$ 混注前対照（右「サ」 前及び後 $1^{\mathrm{h}}$ ),
15）混注後 $30^{\mathrm{m}}$ 及び $2^{\mathrm{h}}$,
F)
16) チフス菌ワクチン $0.1 \mathrm{mg} / \mathrm{kg}$ と $g$-Strophanthin $0.06 \mathrm{mg} / \mathrm{kg}$ 混注前対照 (右「サ」後 $1^{\mathrm{h}}$ ),
17) 混注後 $30^{\mathrm{m}}$,
18) 混注後 $2^{\mathrm{h}}$. 


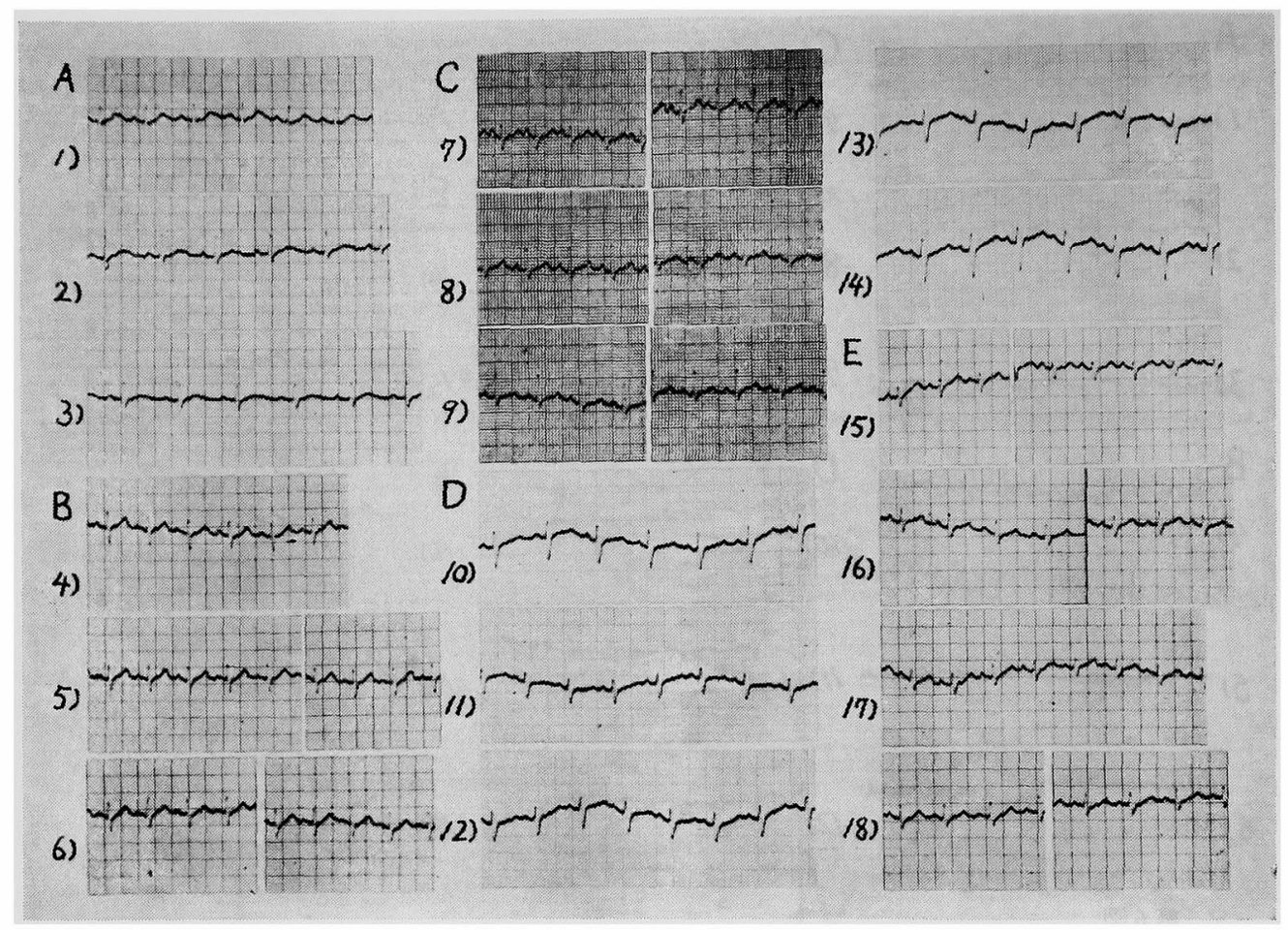

第 7 図.
A)
1）チフス菌ワクチン $0.1 \mathrm{mg} / \mathrm{kg}$ と Digitamin $1 \mathrm{cc} / \mathrm{kg}$ 混注前対照（右「サ」後 $1^{\mathrm{h}}$ ),
2) 混注後 $30^{\mathrm{m}}$,
3) 混注後 $2^{\mathrm{h}}$,
B)
4) T.T.G. $15 \gamma / \mathrm{kg}$ 静注前対照 (右「サ」後 $1^{\mathrm{h}}$ ),
5) 静注後 $30^{\mathrm{m}}$, 及び $1^{\mathrm{h}}$,
6) 静注後 $2^{\mathrm{h}}$ 及び $3^{\mathrm{h}}$,
C)

7） T.T.G. $15 \gamma / \mathrm{kg}$ と $g$-Strophanthin $0.06 \mathrm{mg} / \mathrm{kg}$ 混注前対照（右「サ」前及び後 $1^{\mathrm{h}}$ ),

8) 混注後 $30^{\mathrm{m}}$ 及び $1^{\mathrm{h}}$,

9) 混注後 $2^{\mathrm{h}}$, 及び $3^{\mathrm{h}}$,

D)

10）右「サ」家鬼に DNP $10 \mathrm{mg} / \mathrm{kg}$ 静注直前（対照），

11) 静注後 $30^{\mathrm{s}}$,

12）静注後 $5^{\mathrm{m}}$,

13）静注後 $30^{\mathrm{m}}$,

14) 静注後 $2^{\mathrm{h}}$,

E)

15） DNP $10 \mathrm{mg} / \mathrm{kg}$ と -Strophanthin $0.06 \mathrm{mg} / \mathrm{kg}$ 混注前対照（右「サ」前及び後 $1^{\mathrm{h}}$ ),

16) 混注後 $30^{\mathrm{m}}$ 及び $1^{\mathrm{h}}$,

17) 混注後 $2^{\mathrm{h}}$,

18）混注後 $3^{\mathrm{h}}$ 及び $4^{\mathrm{h}}$. 


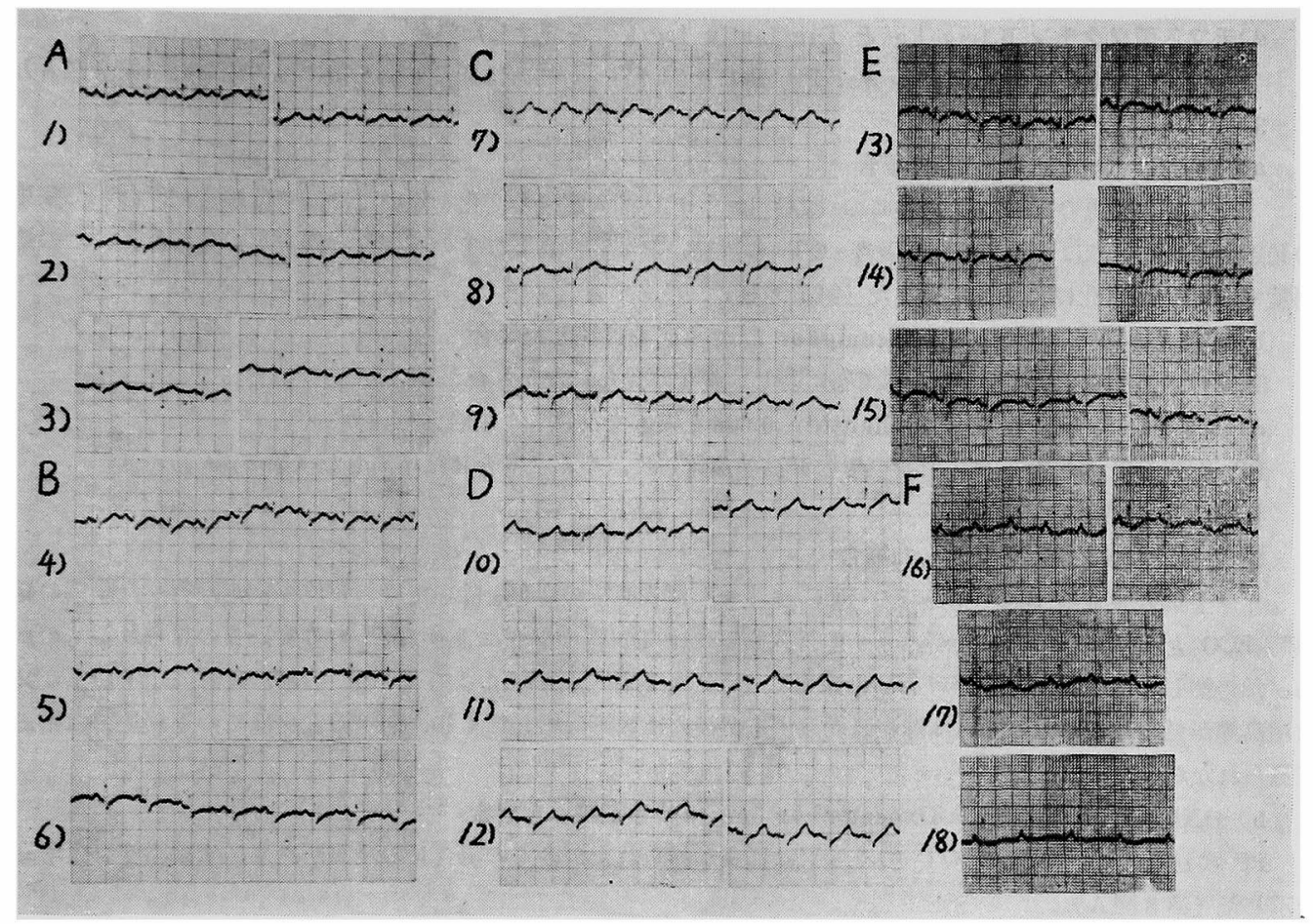

第 8 図。
A)
1) DNP $10 \mathrm{mg} / \mathrm{kg}$ と $t$ - $\pi$-Oxocamphor $5 \mathrm{mg} / \mathrm{kg}$ 混注前対照（右「サ」前及び後 $1^{\mathrm{h}}$ ）,
2) 混注後 $30^{\mathrm{m}}$ 及び $1^{\mathrm{h}}$,
3）混注後 $2^{\mathrm{h}}$ 及び $3^{\mathrm{h}}$,
B)
4）右「サ」家鬼に血液一チフス菌ワクチン $7.5 \mathrm{cc} / \mathrm{kg}$ と $t-\pi$-Oxocamphor $7.5 \mathrm{mg} / \mathrm{kg}$ を混注直前（対照），
5) 混注後 $30^{\mathrm{m}}$,
6) 混注後 $2^{\mathrm{h}}$,
C)
7）右「サ」家鬼に血液一チフス菌ワクチン $7.5 \mathrm{cc} / \mathrm{kg}$ と $g$-Strophanthin $0.06 \mathrm{mg} / \mathrm{kg}$ を混注直前（対照），
8) 混注後 $30^{\mathrm{m}}$,
9) 混注後 $2^{\mathrm{h}}$,
D)
10） $t$ - $\pi$-Oxocamphor $5 \mathrm{mg} / \mathrm{kg}$ 静注前対照（左右「サ」前及び後 $1^{\mathrm{h}}$ ),
11）静注後 $30^{\mathrm{m}}$ 及び $1^{\mathrm{h}}$,
12）静注後 $2^{\mathrm{h}}$ 及び $3^{\mathrm{h}}$,
E)
13） $g$-Strophanthin $0.06 \mathrm{mg} / \mathrm{kg}$ 静注前対照（左右「+」後 $1^{\mathrm{h}}$ ),
14）静注後 $1^{\mathrm{h}}$ 及び $2^{\mathrm{h}}$,
15）静注後 $3^{\mathrm{h}}$ 及び $4^{\mathrm{h}}$,
F)
16) $g$-Strophanthin $0.075 \mathrm{mg} / \mathrm{kg}$ 静注前対照（左右「サ」後 $1^{\mathrm{h}}$ ) 及び静注後 $30^{\mathrm{m}}$,
17) 静注後 $2^{\mathrm{h}}$,
18）静注後 $3^{\mathrm{h}}$. 
d)チフス菌ワクチン $0.1 \mathrm{mg} / \mathrm{kg}$ と Digitamin $1 \mathrm{cc} / \mathrm{kg}$ を混注した場合

多くの場合 QRS の延長が見られた，PP，PQ 及び QT あ初めは延長したが後には短緛した（第 7 図A）

3) T.T.G. 発熱時の ECG

a) T.T.G. 15r $/ \mathrm{kg}$ を静注した堭合

「サ」捅入家鬼の T.T.G. 発熱時の ECG は「サ」插入直後の変化を除いては，背位固定だけ行った家霓 の発熱㭙 ECG とほぼ同栚で，PP：及び QT の短縮，P減高，R及びTの不変及は增高等が見られた，この適 用量ではST の変化は見られなかった（第 7 図B）。

b) T.T.G. $15 r / \mathrm{kg} と t$ - $\pi$-Oxocamphor $5 \mathrm{mg} / \mathrm{kg}$ を混注した場合

T.T.G. 単独静注のとさとくらへてて特に著しい変化は見られなかった。

c) T.T.G. $15 \gamma / \mathrm{kg}$ と g-Strophanthin $0.06 \mathrm{mg} / \mathrm{kg}$ を混过した場合.

$\mathrm{PP}$ 及び QT の柽度延長，P及びTの減高等が見られ，多くの場合Rは增高した（第 7 区C）。

4) DNP 発熱㭙の ECG

a) DNP $10 \mathrm{mg} / \mathrm{kg}$ を静注した堨合

「サ」捙入冢秉の DNP 発熱時の ECG は「サ」挿入直後の変化る除いては，背位固定だけ行った家鬼の発

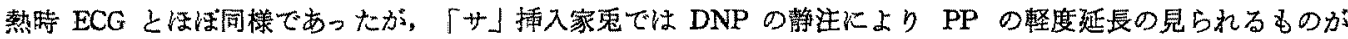
あった，然し多くは背位固定たけ行った家鬼に DNP を静注した場合のよらに PP 短縮， R減高，Tの不変又 は增高等が見られた．Sの深さは静注庭後減ずるが後には次第に增してくる.ST の变化はこの適用量では殆ん ど見られなかった（第７図D）。

b) DNP $10 \mathrm{mg} / \mathrm{kg}$ と t.r-Oxocamphor $5 \mathrm{mg} / \mathrm{kg}$ を混注した場合

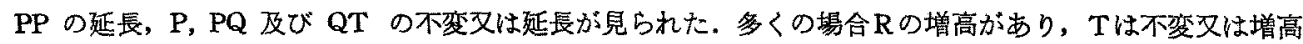
を示した（第8国A）。

c) DNP $10 \mathrm{mg} / \mathrm{kg} と g$-Strophanthin $0.06 \mathrm{mg} / \mathrm{kg}$ を混这 Lた場合

PP 延長，R增高，Tの不変又は增高等が見られた（第 7 図 E).

5) 血液一チフス菌ワクチン発熱時の ECG

a) 血液一チフス菌ワクチン $7.5 \mathrm{cc} / \mathrm{kg}$ と $t$ - $\pi$-Oxocamphor $7.5 \mathrm{mg} / \mathrm{kg}$ を混注した槒合

PP 及び QT の延長，P及びTの減高等が見られた（第 8 図B）。

b) 血液一チフス菌ワクチン $7.5 \mathrm{cc} / \mathrm{kg}$ と $g$-Strophanthin $0.06 \mathrm{mg} / \mathrm{kg}$ を湿这した場合

PP 及び QT の延長，R增高，T減高等が兒られた（第 8 図C）.

6) 諸種薬物による ECG の変化

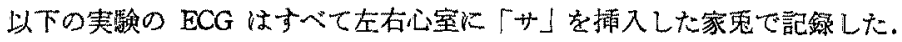

a) t- $\pi$-Oxocamphor

$t$ - $\pi$-Qxocamphor $5 \mathrm{mg} / \mathrm{kg}$ を静注すると, 静注後約 $30^{\mathrm{m}}$ から $1^{\mathrm{b}}$ までは $\mathrm{PP}, \mathrm{PQ}$ 及び QT の延長が見 られたが，約 $3^{\mathrm{h}}$ で殆えど静注前の ECGに回復した．多くの場合Rの增高が見られた(第 8 图D)，7.5mg/kg

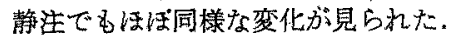

b) g-Strophanthin

g-Strophanthin $0.06 \mathrm{mg} / \mathrm{kg}$ 静注では，PP 延長とR增高が見られたが，QT 短觰或は ST 下降は渚明て なかった（第 8 図E）。

g-Strophanthin $0.075 \mathrm{mg} / \mathrm{kg}$ 静注では，PP 及び PQ は延長した。QT は初めは軽度延長し，後仙は㒖

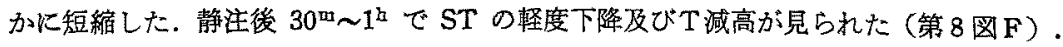

c) Digitamin

Digitamin $1.5 \mathrm{cc} / \mathrm{kg}$ の静注で，PP の延锿及び QT の軽度短縮が見られた。 Tが稍々減高するものも あった。

Digitamin 2cc/kg 静注では，PP 及び QRS の延長があり，QT は稍々短䑮した 㕛R增高し ST の 


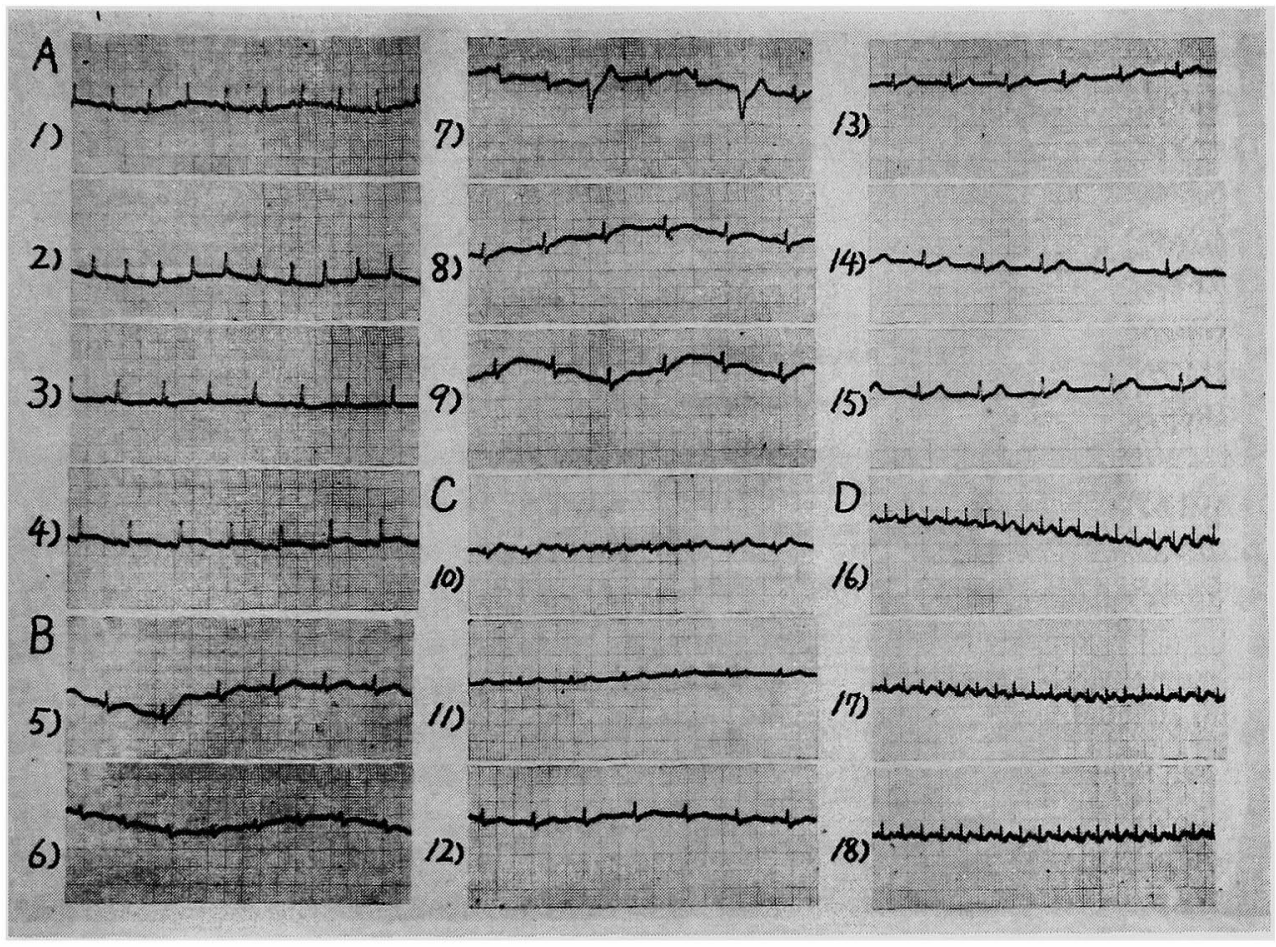

第 9 図.
A)
1) Digitamin $2 \mathrm{cc} / \mathrm{kg}$ 静注前対照 (「ト」前 $\left.1^{\mathrm{h}}\right)$,
2) 左右 $「+」$ 後 $1^{\mathrm{h}}$,
3) 静注後 $30^{\mathrm{m}}$,
4）静注後 $2^{\mathrm{h}}$,
B)
5) Acetylcholine $20 \gamma / \mathrm{kg}$ 静注前対照 (左右「サ」後 $1^{\mathrm{h}}$ ),
6) 静注後 $1^{m}$,
7) 静注後 $3^{\mathrm{m}}$,
8) 静注後 $30^{\mathrm{m}}$,
9）静注後 $2^{\mathrm{h}}$,
C)
10) Acetylcholine $50 \mathrm{r} / \mathrm{kg}$ 静注前対照 (「サ」前 $1^{\mathrm{h}}$ ),
11）左右「サ」後 $30^{\mathrm{s}}$,
12）左右「芫」後 $1^{\mathrm{h}}$,
13）静注後 $30^{\mathrm{s}}$,
14) 静注後 $30^{\mathrm{m}}$,
15）静注後 $2^{\mathrm{h}}$,
D)
16) Imidalin $2.5 \mathrm{mg} / \mathrm{kg}$ 静注前対照 (左右「甘」後 $1^{\mathrm{h}}$ ), 搬送速度 $2.5 \mathrm{~cm} / \mathrm{sec}$,
17) 静注後 $30^{\mathrm{s}}$,
18）静注後 $2^{\mathrm{m}}$. 


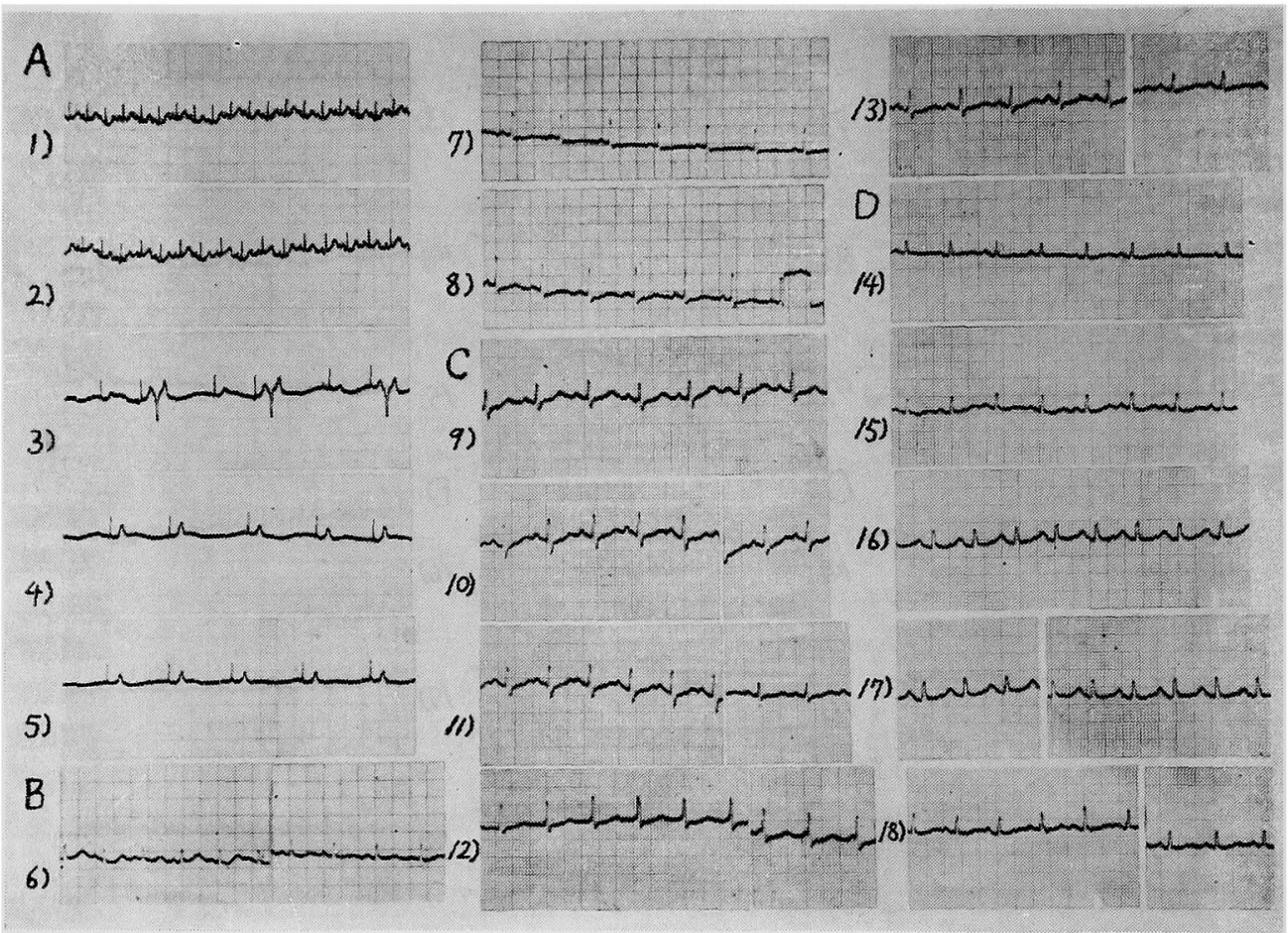

第10図.
A)
1) Adrenaline $25 r / \mathrm{kg}$ 静注前対照（左右「サ」後 $1^{b}$ ), 搬送速度 $2.5 \mathrm{~cm} / \mathrm{sec}$,
2) 静注後 $10^{\mathrm{s}}$,
3）静注後 $30^{\mathrm{s}}$,
4) 静注後 $3^{\mathrm{m}}$,
5) 静注後 $5^{\mathrm{m}}$,
B)
6) Adrenaline $25 r / \mathrm{kg}$ 静注前対照 (左右「サ」前及び後 $1^{\mathrm{h}}$ ),
7) 静注後 $30^{\mathrm{m}}$,
8) 静注後 $1^{\mathrm{h}}$,
C)
9) Atropine $0.5 \mathrm{mg} / \mathrm{kg}$ 静注前対照 (「サ」前 $1^{\mathrm{h}}$ ),
10) 左右「サ」後 $1^{\mathrm{h}}$, 及び静注後 $2^{\mathrm{m}}$,
11）静注後 $5^{\mathrm{m}}$ 及び $7^{\mathrm{m}}$,
12）静注後 $10^{\mathrm{m}}$ 及び $12^{\mathrm{m}}$,
13）静注後 $2^{\text {h }}$ 及び $4^{\text {h }}$,
D)
14) Quinidine $10 \mathrm{mg} / \mathrm{kg}$ 静注前対照 (「サ」前 $1^{\mathrm{h}}$ ),
15）左右「サ」後 $1^{\mathrm{h}}$,
16）静注後 $30^{\mathrm{s}}$,
17）静注後 $1^{\mathrm{m}}$ 及び $2^{\mathrm{m}}$,
18）静注後 $1^{\mathrm{h}}$ 及び $4^{\mathrm{h}}$. 
上界が見られた（第 9 因A）。

\section{d) Adrenaline}

Adrenaline $25 \mathrm{r} / \mathrm{kg}$ 静注では, 直らに徐脈, 洞性及び心室性不整脈, T及びRの增高, ST の下降等が見

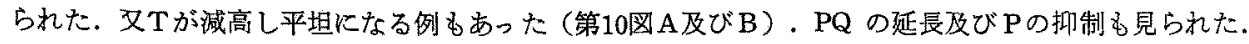

e) Imidalin

Imidalin $2.5 \mathrm{mg} / \mathrm{kg}$ 静注では, 特炕著しい変化は見られなかった．然し静注直後に軽度な ST 上界の見 られたものがあった（第 9 図D）。

\section{f) Acetylcholine}

ACh $20 \mathrm{r} / \mathrm{kg}$ 静注では，静注後 $30^{\mathrm{s}} \sim 3^{\mathrm{m}}$ で PP の短維が見られ，又P及び QT も僅か炕短縮した。 $5^{\mathrm{m}}$ 位経過すると PP は延長し QT る稍々延長した。其の他Rの減高や ST の軽度下降が見られた，洞性徐脈の 外に心室性不整脈を生じたものもあった，又 PP は約 $2^{\mathrm{h}}$ ではほぼ静注前の值に回復した（第 9 图B）。

ACh $50 \mathrm{r} / \mathrm{kg}$ 静注では, 静注後 $30^{\mathrm{s}}$ で PP の延長及び QT の軽度延長があった. PP の延長は $4^{\mathrm{h}}$ 後でも 見られた. 又Rの減高及びT增高を生じたるのが多かった。1〜2

\section{g) Atropine}

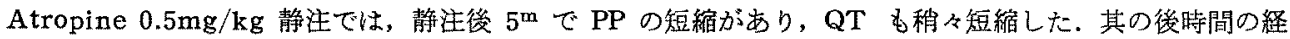
過と共に PP は延長した，其の他 $\mathrm{P}$ 減高, ST の軽度下降及びR增高が一過性に見られたものもあったＰP の 延長は $4^{\mathrm{h}}$ 後ですまだ見られた（第10図C）。

Atropine $0.75 \mathrm{mg} / \mathrm{kg}$ でもPP の延長が見られた.

h) Quinidine

Quinidine $10 \mathrm{mg} / \mathrm{kg}$ の静注では, PP は静注後 $5^{\mathrm{m}}$ 位むでは短縮したが, 其の後沃第に回復し静注前の 檤にかえった， PQ 及び QRS の延長は静注直後から約 $2^{\mathrm{m}}$ まで見られた．丁は延長して增高した $\mathrm{P}$ 重なる （第10図D）。又Sの深くなるもの多く見られた。

$$
\text { 考察 }
$$

私はさきに二，三の細菌性発熱物犋及び DNP による心藏並に直腸の各発熱時の温度を比較したが，今回

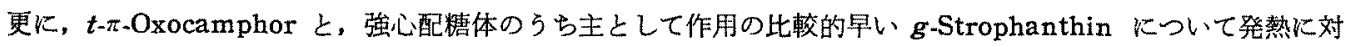

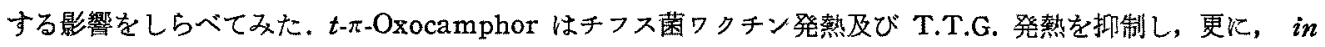
vitro で血漿との相互作用により altered form の Endotoxin を生ずると考えられる血液一チフス菌ワクチ ンの発熱も著しく抑制した．然し DNP 発熱に対しては殆んど抑制しないばかりかか兄って稍々増強させた。 $\boldsymbol{g}$-Strophanthin はチフス菌ワタチン発熱及び血液一チフス菌ワクチン発熱に対しては, $\boldsymbol{t}$ - $\pi$-Oxocamphor $亡$ 同様に抑制を示した。然し T.T.G. 発熱に対しては, この適用量では抑制は著しくなく，発熱初期の心内温の

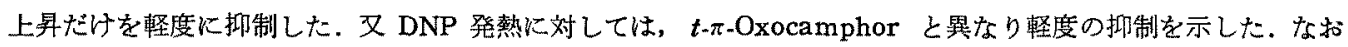
チフス菌ワクチン発熱汶しては Digitamin る使用してみたが，失張り抑制が認められた．

$\boldsymbol{t}-\pi$-Oxocamphor の比較的大量が解熱作用を示すことはすでによく知られている。解熱機転については， この薬物の中枢作用から考えて恐らく直接に体温調節中枢作用し，皮膚（家农では主として耳翼皮虔）の表在 性血管の拡張を来吉たると考えられていたが，今回の寒駼で血液一チフス菌ワクチン発熱を著しく抑制した事， 及びすでに鳴沢13) をはじめ其の他の人ふにより主として末梢的な発熱を生ずると云われているDNP 発熱に対 しては抑制が殆んど見られずもしろ稍々增強する傾向のあった事は，従来のこの教充方を或る程度裏付けるすの と云えよう.

背位固定正常家鬼に $t-\pi$-Oxocamphor 峃独で静注しても, 静注後数分以内に左右心内温及び直腸温の一 時的下降を生したが，右心内温，左心内温，直腸温の順で回復し，後には三温とも稍々温上升が見られた。即ち 正常家稂记対し体温下降作用はあっても弱いことがかかる。

$g$-Strophanthin は一方 $t$ - $\pi$-Oxocamphor と同様に血液一チフス菌ワクチン発熱を著しく抑制するかと思 


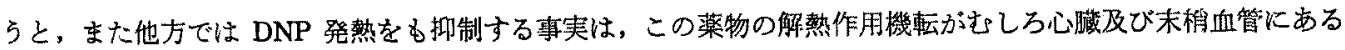
ことを推定させる，発熱の初期比末梢血管の収縮を生じ，血流速度が速くなることはよく知られている。

Weil たち ${ }^{14)}$ は Endotoxin の注射後的 $1^{\mathrm{h}}$ む続く閥压の上年を報告し，これは心搏出量を減少させる とのべている。このように発熱時术梢血管收縮並に心搏出量の減少がある場合に，g-Strophanthin (Digitam

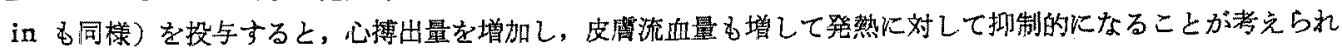
る。これは清川たち(16) が所謂らっ熱の状態に対して，強心削がうっ血状態を除去することにより微熱を平熱化 するとのべているのと同様な機転ではなかるらか。

g-Strophanthin 並に Digitamin を背位固定正常家來にそれぞれ単独に静注すると， $g$.Strophanthin で は静注直後には左右心内温及び直腸温山何れる殆んど变化がなかったが，約 $15^{\mathrm{m}}$ 位経過するとそれぞれ僅が 上㫒し，中でも左心内温の上昇が最む大であった。 又 Digitamin では $1.5 \mathrm{cc} / \mathrm{kg}$ 静注の場合では $1^{\mathrm{b}} 30^{\mathrm{m}}$ 位で 左右心内温及び直腸温の上年があるが，投与量を增すとこの上界が早く現われる.上界度は g-Strophanthin の場合と同棣に左心内温が最も大きい，Digitamin の場合には特に筋温も測定したが，投与量を增すと他の心 内温及び直晹温に見られる様な上昇がなく，逆に下降を続けることがかかった。

$g$-Strophanthin 及び Digitamin は正常家鬼では，発熱時と異なり皮居流血量索減少させるといるれてい る。これが心内温及び直晹温を上年させる主な原因であるう。Digitamin の投与量を增したとき，觔温が下降 を䋨けたのは筋肉が比較的表在性の組織であり，初期の温下降が強くあらわれ，そのために其の後回復の㖽向は 示しながら静注前温度以上に上年することが出来なかったと考完られる. 又 $g$-Strophanthin 又は Digitamin の静注で，左心内温の上年が他に比較して稍々大であったのは，松永息が g-Strophanthin について行った左 右心筇温の上昇度の比較実験の結果に上く似ている。強心配煻体に上る心筇の収縮力の增強が左心内温何等か の影響を与えるのかる知礼ない。

な敌実験 Aに於ける

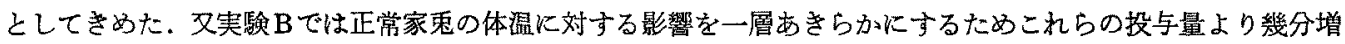

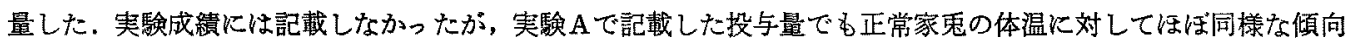
が見られたのである。

Adrenaline の体温汶する作用については多くの場合無固定の正常動物で $0.2 \sim 0.5 \mathrm{mg} / \mathrm{kg}$ 皮注の影響が

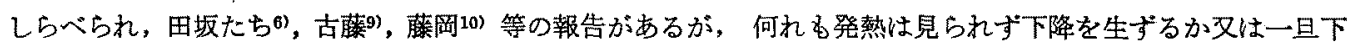

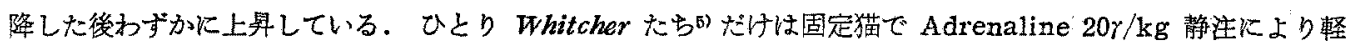
度の直䐺温上年を観察しているが，静注後長時間にわたる観察をしていない，本実験では Adrenaline 静注後 左右心内温の上昇が見られた。然し直腸温は温上年が極めて僅かであり，後には筇温と同様に基線以下に下降し た.この静注直後の心内温及び直晹温の上身は括そらく末梢血管収縮のためであ万らが，左右心内温㥀腸温之

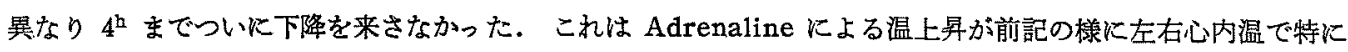
大さいためであると解釈される。筋温は Adrenaline 静注で下降した。これはやはり比較的表在性の組織であ

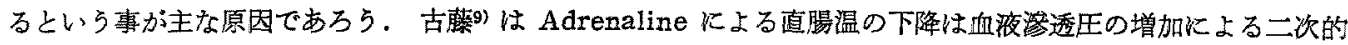
な体温調節中权の興榣の結果であると云っている。

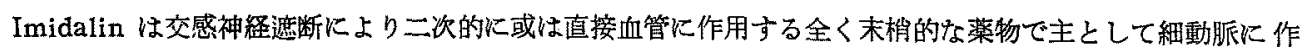
用するるのと云われている，本実験では各温とる一旦静注前の温度以下に下降したが，やがて各温とる上年し た. 初期の下降は Imidalin に上る皮獻在性血管の拡張によるものと考光られ，Deutschたち2)もラットで

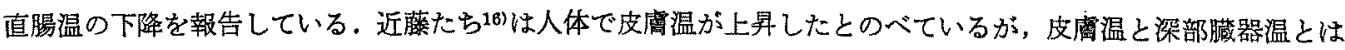
多くの場合，温度曲線が互に基線をはさんで鏡面像をなするのであるから以上の説明と矛盾しない，

$\mathrm{ACh} 50 \% / \mathrm{kg}$ 静注では，腹温だけが静注直後上年し，次いで基線以下に下降した。左右心内温及び直腸温 は何孔も直後から下降した. 然し $25 \mathrm{r} / \mathrm{kg}$ 静注の場合には, 心内温及び直腸温は注射直後の下降の後, すぐ回復 し，更汇僅が上界したが結局基線以下に下降した．ACh は細動脈及び毛細血管に影響を与えると云かれる。 一般に皮有表在性血管を执張するため心内温及び直腸温の下降を生ずるが，此較的大量の ACh 静注直後では骨 
格筋が収縮するため筇温の上界が見られるのであるう。

Atropine $0.5 \mathrm{mg} / \mathrm{kg}$ 静注では筋温のみ上年し，他の三温は基線以下に下降したが， $0.75 \mathrm{mg} / \mathrm{kg}$ では左右 心内温及び直腸温は静注直後上界し, 笳温は一時下降するがすぐ上界し初ぬ静注前温度まで回復した。然し其の 後は時間の経過沉つれて 4 温とす基線以下に下降した. Atropine では皮成の表在血管は厸張されるから深部臟 器温の下降を来するのと考光られる．ここでもやはり筋温怯心内温や直晹温にくらべて, 比較的表在性温度であ るといら事が，温度経過の上での相違を生じたものと思えれる.Atropine の投与量を增加した埸合瀞注直 後の心内温及び直晹温の上年を見たのは，この投与量では静注直後に直接体温調節中枢作用する事も考えられ るが，その外，一過性の皮膚の表在性の血管收縮もあったのではなかららか。

Quinidine では各温とも温上䄯はなくて，時間の経過につれて基線以下に下降した．左右心内温に対して もあまり影響がなかった．Quinidine は解熱作用をもっているが正常体温に対しても軽度の抑制作用を持って いるよらに思われる.

次に ECG については，「サ」挿入直後には実験成績でのべた樣な著明な変化を生ずるが，約 $20^{\mathrm{m}}$ 以上経 過すると多くの場合不整脈を見ることは少なく，又「サ」㨉入後 $4^{\mathrm{h}}$ までの ECG でばST の deviation も見 られなかった．更に「サ」挿入家鬼と正常家鬼の発熱物質並に諸種薬物に上る ECG の変化を比較したが大きな 相遠は認められなかった。

前報12) 及び今回の実験はすべて「サ」㩕入後 $1^{\mathrm{h}}$ 経過してから，発熱物質又は薬物を静注しており，この 時期では「サ」の捙入が心蔵に対して少くとも ECG の上では著明な影響を与えていない事がわかる.

田坂たち17情脈カテーテルを行った場合には，心房性並に心室性不整脈が見られ，時に脚ブロックを生ず ることがあるとのべているが，本実験でも初期汇洞性並に心室性不整脈が見られた．不整脈以外の変化としては 何れも軽度ではあるが, PP 及び QT 延長, P短縮, QRS の延長, R增高及びT減高等が主なるのである.

今回使用した発熱物質及び諸種薬物の ECG についてはすで諸家の報告があるが，その適用量，使用動物 の如何によりその結果は必ずしも一致しているとは云えない，この実験では温度経過の観察を主とし，ECGの 記録を従としたものであり，その点投与量にある程度の制限を加劣ざを得なかった。

発熱物質又は諸種薬物投与による ECG の変化の内, 主なるのについて先人の業䋶と比較してみると, まず

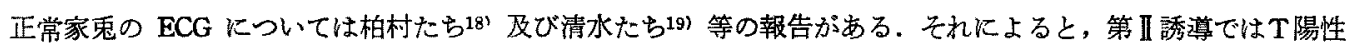
で ST の下降したものは殆んどなく，又下の変動は此較的少ないといら．然し時間的因子については可成りの variation があるとのべている.

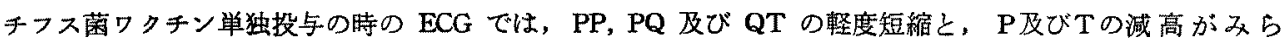

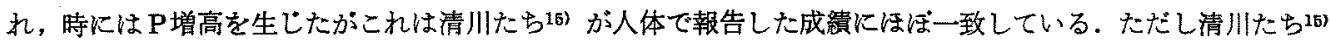
が埌告しているよらな ST の陰性化は見られなかった．T.T.G. 単独投与では，PP 及び QT の短縮，P減高， R及びTの不変又は增高等がみられたが，清川たち15) は矢張り人体で, PP, QT の短縮を認めてはいるが，そ

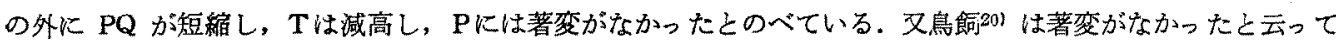
いる. DNP 単独投与では PP 短縮, Tの不变又は增高, Rの減高等をみたが, Nawata ${ }^{211}$ は ST, T 上界を, 田坂たち229) は軽度のT增高を報告している. Digitamin 単独投与で，PP の延長，QRS の延長，QT の軽度 短縮， $\mathrm{R}$ 堌高， $\mathrm{ST}$ 上年及びTの軽度堿高を認め, 叉 $g$-Strophanthin 単独投与では $\mathrm{PP}$ 及び $\mathrm{PQ}$ 延長, $\mathrm{QT}$ 短 樎，ST の軽度下降， R增高及びT減高等を認めた. ジギタリスによる ECG の変化については青木23), 宮沢24),

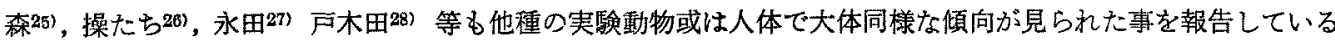
が，ST 上年についてはのべていない，又藤沢29) は家航で $g$-Strophanthin の大量を投与するとT反転, ST 下降，心房細動，QRS 桩大，心室性期外収縮等が見られたという。Adrenaline 単独投与の所見は，島本た ち30), Samaan ${ }^{311}$, Hoff たち ${ }^{32)}$ 等の報告とほほ同様な傾向がみられた，Imidalin 単独投与では特に著明な变化 は見られなかったが，軽度な ST 上䄯が見られた. Kaufmanたちがは心搏には著変がなかったとのべている。 $\mathrm{ACh} 20 \gamma / \mathrm{kg}$ 静注では, 直後に PP 短縮, 軽度のP及び QT 短縮等がみられたが, 数分後には PP は延長し, $\mathrm{QT}$ も稍々延長した，其の他 $\mathrm{R}$ 減高, ST 軽度下降，時には心室性不整脈等が生じた。然し $50 \mathrm{r} / \mathrm{kg}$ 静注で 
は, 直後から PP の延長及び QT の軽度延長があり，其の他 R 減高や T增高が見られた。古家 ${ }^{24)}$ は大量の $\mathrm{ACh}$ で徐脈, T逆眃, ST 下降, 期外収縮等が見られたとのべている. Atropine $0.5 \mathrm{mg} / \mathrm{kg}$ 静注では, 直後に PP

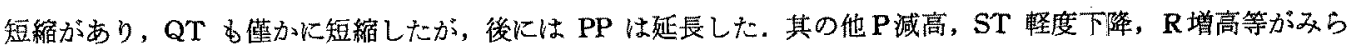

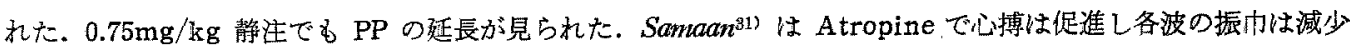

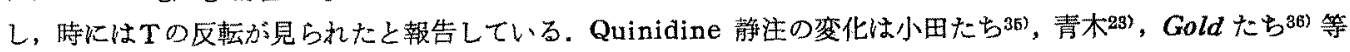
が報告している所見に大体一致している。要するにこれら ECG の諸変化は発熱性物質を始め諸種薬物の影響に 基くものであることはもちろんであるが，発熱現象自体の影響に基くものとは考光にくい。

総括

家秉を背位に固定しその心内温，直腸温及び筋温（大腿内転労）をサーミスターによって測定した。

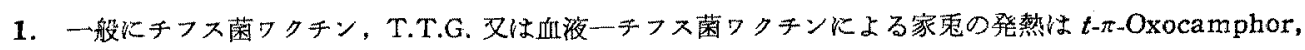

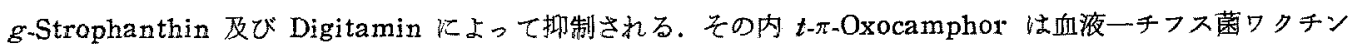
発熱を最も著しく抑制するのに DNP 発熱には殆んど影響しない。

2. $t$ - $\pi$-Oxocamphor では静注直後各温の下降を生じ，直腸温の下降が最も大きい，然し後には各温とむ 上升し右心内温の上䄯が一番大である. $g$-Strophanthin 及び Digitamin では一般に左心内温の上昇が最む大 きい，Adrenaline静注は心内温の上年を生ずるが筋温及び直晹温は下降する，Imidalin では各温の下降を生ず る. Acetylcholine で性静注直後筋温だけが上昇し，他の各温は下降する。後には筋温も下降する。Atropine では各温の下降を生ずるが， $0.5 \mathrm{mg} / \mathrm{kg}$ 静注の場合は筋温は初め上昇し，後下降する。 Quinidine では各温は 殆んど不変か或懽かに下降する.

3.「サ」雨入家乐で発熱物質及び諸種薬物によるECG の变化をしらべた．

「サ」插入直後一過性の洞性或は心室性不整脈をみる。チフス菌ワクチンでは PP, P 及び QT 短縮, P及びT減高を, T.T.G. では PP 及び QT 短樎, P減高をみる. DNP では PP 短縮, R減高, Tの不変又 は增高を生ずる. $t$ - $\pi$-Oxocamphor では $\mathrm{PP}, \mathrm{PQ}$ 及び $\mathrm{QT}$ の延長，R增高を，g-Strophanthin では一般に PP 延長， ST 軽度下降，T減高及びR増高を兒る，QT は初め延長後短縮する．Digitamin では ST の上年 を見ることがあるが其の他の変化は $g$-Strophanthin の場合とほぼ同様である. Adrenaline では徐脈，洞性

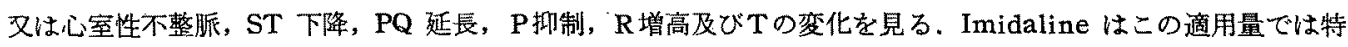
飞著変を認めないが, 一過性に ST 上算を見る. ACh では一般に PP, PQ 及び QT の延長， R 減高及びT増

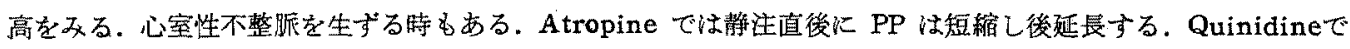
は $\mathrm{PQ}$ 及び QRS は延長し，TとPが重畳する. 刃Sが深くなる。

\section{引 用}

1) Deutsch, E. たち : Arch. int. Pharmacodyn. 85, 369 (1951).

2) Deutsch,E.たち:同 誌 93,400 (1953).

3) Graf, W. たち : Acta physiol. scand. 41, 139 (1957).

4) Wakim, K. G. たち : Arch. Physiol. Med. 32, 714 (1951).

5) Whitcher, C. E. たち : Amer. J. Physiol. 156, (1949).

6）田坂たら：日新医学 40，545（1953）.

7）松永たち：日生理誌 12, 27（1950）.

8）松永：日循誌 16，82（1952）.

9）古藤：日薬理誌 48, 1408 (1952).

10）藤岡：麻布獣医学矿究報告 2 号 79 (1955).

11) 横井：日新医学 41，175 (1954).

12）安田：日薬理誌 56, 270 (1960). 
13）䳛沢：同誌 52,820 (1956).

14) Weil, M. H. たち : J. clin. Invest. 35, 1191 (1956).

15）清川たら：日偱誌 17，297（1953）。

16）近藤たち：日新医学 37，373(1950).

17）田坂たら：心内静脈カテーテル法 84 (1953).

18）柏村たら：日循誌 17，115（1953）.

19）清水たら：同誌 12，118（1948）。

20）鳥飼：日新医学 41, 173 (1954).

21) Nawata，Y：日循誌 20，291（1956）.

22）田坂たち：同誌 20，298（1956）.

23）青木：日薬理誌 51，134§ (1955).

24）宮沢：札幌医誌 7，280 (1955).

25）森：日薬理誌 $\mathbf{5 0}, 14 \S(1954)$.

26）操たら：日循誌 16，209（1952）。

27) 永田：同誌 14, 117 (1950).

28）戸木田：日薬理誌 53，348(1957).

29) 藤沢: 同誌 50, 242 (1954).

30）島本たら：同誌 53，660（1957）.

31) Samaan, A. : Arch. int. Pharmacodyn. 50, 101 (1935).

32) Hoff, H. E. たち : J. Pharmacol. 52, 235 (1934).

33) Kaufman, J. たち : Angiol. 1, 515 (1950).

34) 古家：日薬理誌 55, 1156 (1959).

35）小田たち：日大医誌 12，605 (1953).

36) Gold, H. たち : J. Pharmacol, 46, 357 (1932). 